\title{
Penyelesaian Numerik Hamburan Kuantum Potensial Sentral Dengan Metode Runge-Kutta
}

\author{
Firdaus Ariefatosa $^{1}$, Budi Santoso ${ }^{1}$, Muzilman Muslim ${ }^{1}$, Ari Mutanto ${ }^{1}$ \\ ${ }^{1}$ Program Studi Fisika, Fakultas Teknik dan Sains, Universitas Nasional Jakarta \\ E-mail : profbudis@yahoo.com
}

\begin{abstract}
ABSTRAK. Telah dilakukan perhitungan tampang lintang total hamburan dengan metode gelombang parsial. Dalam metode ini, besaran yang menjadi kunci adalah geser fasa $\delta 1$ diperoleh dengan menyelesaikan persamaan diferensial bagian radial hamburan kuantum dengan dan tanpa potensial penghambur. Perhitungan Numerik yang dipilih adalah metode Runge-Kutta karena kemudahan aplikasi dan akurasi tinggi. Potensial hamburan yang digunakan adalah potensial Coulomb tertirai (Screened-Coulomb) yang telah diketahui parameter-parameter potensialnya sebagaimana telah disajikan oleh Salvat (Salvat et al, 1987) melalui metode variasi medan konsisten. Hamburan yang dimaksud adalah hamburan elektron-atom.
\end{abstract}

Kata kunci: Hamburan Kuantum, Metode Runge-Kutta, Tampang lintang hamburan, Geser fase, Potensial Yukawa, Parameter Potensial Salvat.

\begin{abstract}
A numerical solution of total cross section has been computed by using a partial wave analysis method. The important quantity on this method is a phase shift $\delta l$ which is obtained by a solution of the radial direction of the differential equation both with or without a potential effect of the system. A numerical method presented is an RK method since it's simple application and high accuration characteristic. Screened-Coulomb potensial with the parameters has been served by Salvat (Salvat et al, 1987) with a selfconsistent field variational method was used. The scaterring problem was only limited to the electron-atom collision problem.
\end{abstract}

Keywords: Quantum scattering, Runge-Kutta method, Scattering cross-section, Phaseshift, Yukawa potential, Salvat potential parameter.

\section{PENDAHULUAN}

Proses hamburan telah sejak lama menjadi titik perhatian studi fisika bahkan sebelum kelahiran teori kuantum karena dengan proses ini akan didapatkan cukup banyak informasi mengenai struktur materi. Perkembangan teori kuantum yang terus berkembang telah semakin membuka bertambahnya perangkat-perangkat yang sangat dibutuhkan untuk memperkirakan model interaksi dalam level subatomik sekalipun, dan dengan demikian, ekperimentasi dengan hamburan menjadi sebuah perangkat utama untuk mengenali struktur materi dengan hasil yang semakin akurat.

Hamburan kuantum menjadi metode utama dalam menjajak (probing) ke dalam struktur molekul, atom, inti dan bahkan nukleon. Melalui hamburan Rutherford ditemukan bagaimana model atom yang tepat dan bersesuaian dengan teori yang diakui. Interaksi antar konstituen molekul, atom maupun partikel pada umumnya hanya dapat dipelajari dengan proses teknik hamburan. Melalui hamburan ini, proyektal yang diinjeksikan ke dalam target akan keluar atau terhambur dengan membawa informasi tentang model interaksi yang terjadi di dalam target. yang kesemuanya didapatkan melalui proses penjajakan dengan teknik hamburan.

Jumlah partikel terhambur ke arah sudut tertentu, (disebut $\theta$ ) secara eksperimen dapat diukur. Spektrum energi maupun kerapatan partikel terhambur ini memberikan informasi interaksi apa yang terjadi di dalam target. Fenomena mengenai hal ini, penjelasannya hanya mungkin dilakukan dengan menggunakan landasan teori hamburan kuantum. Dalam hamburan kuantum, model matematika yang kemudian dihasilkan adalah suatu persamaan diferensial orde-dua dalam variabel ruang berdimensi tiga. Dengan menggunakan koordinat bola dapat diperoleh persamaan radial yang memberikan informasi tentang adanya geser fase pada dua keadaan potensial, dimana geser fase adalah penggeseran fungsi gelombang akibat adanya interaksi 
proyektal dengan target berbentuk potensial hamburan. Dalam model ini diambil model potensial statik sentral, artinya potensial tersebut hanya merupakan bentuk fungsi jarak antara partikel dengan titik awal/origin (pusat hamburan $O, r=r 0$ ). Karena berbentuk statik, maka dapat diartikan bahwa fungsi tersebut bukan sebagai fungsi waktu atau energi maupun momentum, atau fungsi non-relativistik.

Model-model potensial yang telah ada antara lain adalah model Yukawa atau Coulomb tertirai (Screened Coulomb), model Exponensial, model Gaussian, model Lennard-Jones dan lain-lain. Setelah suatu model dipilih dalam proses penyelesaian permasalahan, maka permasalahan selanjutnya yang akan dihadapi adalah menyelesaikan persamaan diferensial untuk memperoleh nilai geser fase. Dari geser fase ini akan dapat dihitung tampang lintang hamburan diferensial (differential cross section) yang kemudian dapat dibandingkan dengan harga eksperimen. Nilai tampang lintang hamburan diferensial yang didapat adalah komponen yang diperlukan untuk mengetahui tampang lintang total sebagai kebolehjadian partikel terhambur pada sudut $\theta$.

$$
\sigma=f(\theta) d \theta
$$

Dimana persamaan diferensial yang akan diselesaikan untuk mendapatkan nilai geser fase $(\delta l)$ tersebut digunakan untuk menghitung nilai amplitudo hamburan yaitu,

$$
f(\theta)=\frac{1}{2 i k} \sum_{l=0}^{\infty}(s l+1)\left\{e^{2 i \delta_{l}}-1\right\} P_{l}(\cos \theta)
$$

Karena tidak adanya penyelesaian eksak secara analitik yang tersedia sebagai kerangka teori yang cukup untuk menjelaskan hasil eksperimen hamburan kuantum tersebut, maka hasil analitik didapatkan dengan melakukan metode aproksimasi penyelesaian yang merupakan pendekatan solusi analitik yang dapat digunakan, diantaranya adalah metode pendekatan Born, Eikonal, Pade , metode variasi dan sebagainya. Dengan demikian dipastikan terjadi perbedaan antara nilai tampang lintang diferensial terukur (measured differential cross section) dengan tampang lintang terhitung (calculated differential cross section). Maka dari sini akan muncul pertanyaan apakah model yang digunakan kurang tepat ataukah metode pendekatan yang digunakan kurang akurat.

Kesulitan perhitungan dengan metode analitik pendekatan solusi antara lain disebabkan oleh terlalu rumitnya perhitungan matematis secara analitik itu sendiri, terutama dengan keharusan untuk menyesuaikan dengan model potensial yang paling sesuai. Salah satu jalan keluar adalah dengan menyelesaikan persamaan diferensial menggunakan metode numerik. Menggunakan metode numerik, tiap titik per titik (point-per-point) solusi dapat diuji secara akurat, hanya saja dengan kelemahan memerlukan waktu komputasi yang cukup lama dengan resource komputer tertentu dan kemampuan menulis program komputasi.

Terdapat banyak metode numerik untuk menyelesaikan persamaan diferensial titik per titik, antara lain motode Adam, Backward-forward correction, metode pendekatan selisih (difference approximation), metode Heunn, metode Runge-Kutta dan lain-lain. Metode Runge-Kutta sendiri memiliki banyak model yang kemudian harus dipilih yang memiliki nilai koreksi error/galat paling kecil. Salah satu metode numerik yang telah diuji keandalannya adalah metode RungeKutta dengan koreksi error orde $h$ pangkat lima dimana $h$ merupakan panjang langkah solusi, dengan nilai tipikal $h=0.01$. Keakuratan metode Runge-Kutta yang digunakan dapat diuji dengan melakukan studi tolak ukur akurasi dengan menyelesaikan persamaan diferensial yang memiliki penyelesaian analitik yang sudah diketahui. Inilah uji yang disebut sebagai uji benchmark.

Setelah diperoleh penyelesaian akurat secara numerik, maka program komputer yang dibuat tersebut menjadi software yang dapat dipakai untuk memilih potensial yang hasil perhitungan tampang lintang diferensial-nya sesuai atau setidaknya sedekat mungkin dengan hasil tampang lintang diferensial hasil eksperimen. Penelitian ini hanya dibatasi sampai pada penyusunan perangkat lunak program numerik yang hasilnya dibandingkan akurasinya terhadap metode lain dengan model potensial yang sama. 


\section{METODE DAN BAHAN}

Metode yang dilakukan dalam penelitian ini adalah metode teoritik dimana berdasarkan teori baku dari rumusan matematik. Metode ini bersifat analisis maupun numerik. Langkah-langkah yang dilakukan dalam penelitian ini adalah yang pertama identifikasi masalah yaitu mengindentifikasi fenomena yang akan diteliti. Berikutnya penentuan landasan kerangka analisis sehingga dihasilkan model dan teori yang harus diuji, serta rumusan matematik dalam berbagai bentuk. Selanjutnya melakukan perhitungan dan penyelesaian matematik yang dapat dilakukan dengan analisis atau metode numerik dan pemodelan, dan yang teakhir adalah penafsiran hasil dari motode pemodelan yang dilakukan.

\section{Metode Numerik}

Metode numerik adalah satu-satunya metode alternatif yang ada dalam upaya menyelesaikan persoalan-persoalan matematis. Metode yang lain dikenal dengan sebutan metode analitik. Dua alasan umum mengapa pilihan dijatuhkan kepada metode numerik. Alasan pertama metode ini memberikan keefisienan dan keefektifan di dalam menyelesaikan perpersolan-persoalan matematis dikarenakan berkembangnya perangkat keras dan lunak komputer akhir-akhir ini. Alasan yang lain adalah metode numerik memungkinkan untuk mengkaji parametrik dari persoalan dengan medan yang bersifat sembarang. Alasan yang terakhir ini lebih bermakna ketidakmampuan metode analitik untuk menyelesaikan persolan-persoalan matematis aplikasi yang kompleks. Dalam banyak literatur analisa numerik diungkapkan bahwa di dalam metode numerik keputusan menerima atau menolak suatu jawaban aproksimasi berdasarkan kepada toleransi kedekatan yang disepakati. Toleransi yang dibuat menyangkut kesepakatan kesalahan/galat yang ditimbulkan oleh rumus/formula yang digunakan. Tentu semakin kecil kesalahan/galat yang ditimbulkan oleh penggunaan suatu rumus/formula maka semakin baik hasil aproksimasi yang dihasilkan.

Kemajuan teknologi komputer saat ini memberi peluang besar untuk mendapatkan nilai aproksimasi yang cepat dan akurat yang pada akhirnya meringankan kerja si pengguna metode numerik. Hal ini didasari pada kenyataan bahwa metode-metode yang sudah ada maupun yang sedang dikembangkan memerlukan proses interasi yang cukup panjang. Oleh karena itu tidak cukup memadai bila dikerjakan dengan cara manual maupun menggunakan kalkulator biasa yang telah dikenal. Ada banyak contoh aplikasi matematika yang mengharuskan pilihan dijatuhkan kepada metode numerik ketimbang metode analitik.

\section{Metode Runge-Kutta}

Runge-Kutta memberikan suatu formulasi yang lebih elegan, karena menghasilkan perumusan yang lebih mudah. Untuk lebih memberikan gambaran bagaimana metode Runge-Kutta menyelesaikan persamaan diferensial secara numerik, berikut diberikan uraiannya, sekaligus paparan mengapa metode Runge-Kutta dianggap sebagai metode yang paling efisien. Apabila ingin diselesaikan suatu persamaan diferensial persamaan (3).

$$
\frac{d y}{d x}=f(x, y)
$$

dengan $f(x, y)$ adalah fungsi yang diketahui. Maka dengan bertolak dari titik awal, dengan menggunakan titik $x o=0$, dan harga $y=y o$, akan dapat dicari penyelesaian dititik $(x 0+h)$ dengan menggunakan deret Taylor seperti persamaan 4 dibawah ini.

$$
y\left(x_{o}+h\right)=y_{o}+h f^{\prime}\left(x_{o}, y_{o}\right)+\frac{h^{2}}{2 !} f^{\prime \prime}\left(x_{o}, y_{o}\right)+\cdots
$$

Jika perhitungan dengan deret tersebut dihentikan sampai dengan orde dua, maka kesalahannya adalah pada $h 3$ ( $h$ pangkat tiga) dan seterusnya. Kesalahan yang yang dihasilkan akan bergantung pada banyaknya suku yang digunakan. Selain itu, metode ini semakin kurang praktis, dikarenakan untuk menyelesaikannya kita perlu menyediakan harga derivat atau turunan $f$ sesuai dengan tingkat suku yang dikerjakan, yaitu $f^{\prime}, f^{\prime \prime}, f^{\prime \prime \prime} \ldots$. Semakin tinggi akurasi yang 
diperlukan maka pada umumnya akan semakin sulit memberikan nilai derivat $f$. Hal ini akan semakin rumit apabila suku yang diperlukan untuk mendekati nilai akurasi terbaik terhadap perhitungan analitik mengharuskan perhitungan berhenti setidaknya sampai pada suku keempat atau bahkan lebih. Pemberian turunan $f^{\prime \prime \prime \prime}, f^{\prime \prime \prime \prime \prime}$ dan seterusnya akan semakin mempersulit perhitungan numerik yang akan dilakukan.

\section{Metode Runge-Kutta Orde-4}

Salah satu model Runge-Kutta yang paling sering digunakan lazim disebut dengan metode RK4 (Runge-Kutta Orde 4) atau metode Runge-Kutta klasik atau disebut dengan metode RungeKutta saja. Metode yang ditemukan tahun 1900 ini termasuk salah satu metode dari sekian banyak keluarga metode iteratif implisit maupun eksplisit dalam menghitung pendekatan solusi persamaan diferensial biasa.

\section{HASIL DAN PEMBAHASAN}

\section{Tampang Lintang Total Hamburan $\sigma$ Elektron-Atom}

Hasil perhitungan numerik tampang lintang total hamburan $\sigma$ diberikan untuk beberapa contoh atom yang disajikan dalam bentuk tabel dan plot data untuk masing-masing contoh atom. Program FORTRAN menghasilkan hasil perhitungan tampang lintang total $\sigma$ dari masingmasing atom target untuk tiap-tiap energi proyektal yang bervariasi. Energi yang dipilih sebagai contoh disesuaikan menurut energi-energi proyektal yang disediakan oleh data eksperimen yang diperoleh dari referensi. Besar langkah $h=0.01$ dalam perhitungan Runge-Kutta untuk persamaan diferensial hamburan dianggap sebagai langkah yang cukup efisien dalam perhitungan.

Model potensial yang digunakan adalah model potensial Yukawa (Screened Coulomb) dengan parameter screening yang diberikan oleh persamaan (4) dan sebagai konstanta numerik untuk model potensial yang dipakai adalah potensial Salvat seperti persamaan (5).

$$
\begin{aligned}
& {\left[\frac{d^{2}}{d x^{2}}+\frac{1}{x} \frac{d}{d x}+1-\frac{\left(l+\frac{1}{2}\right)}{x^{2}}\right] y_{l}(x)=0} \\
& U(r)=\sum_{i=1}^{3} A_{i} \frac{e^{-a_{i} r}}{r}
\end{aligned}
$$

\section{Hamburan $e$-Hidrogen}

Pada gambar 1 dapat dilihat tampang lintang total $\sigma$ Hidrogen, Z=1

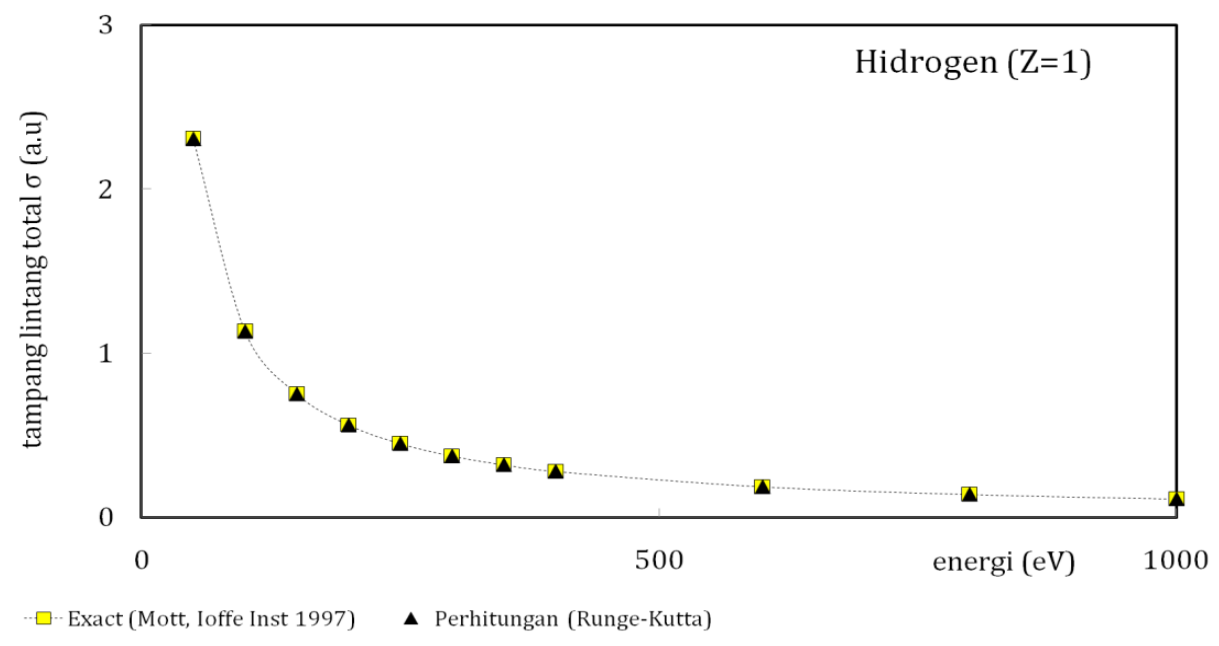

GAMBAR 1. Tampang Lintang Total $\sigma$ untuk Helium 


\section{Hamburan e-Helium}

Pada gambar 2 dapat dilihat tampang lintang total $\sigma$ Helium, Z=2

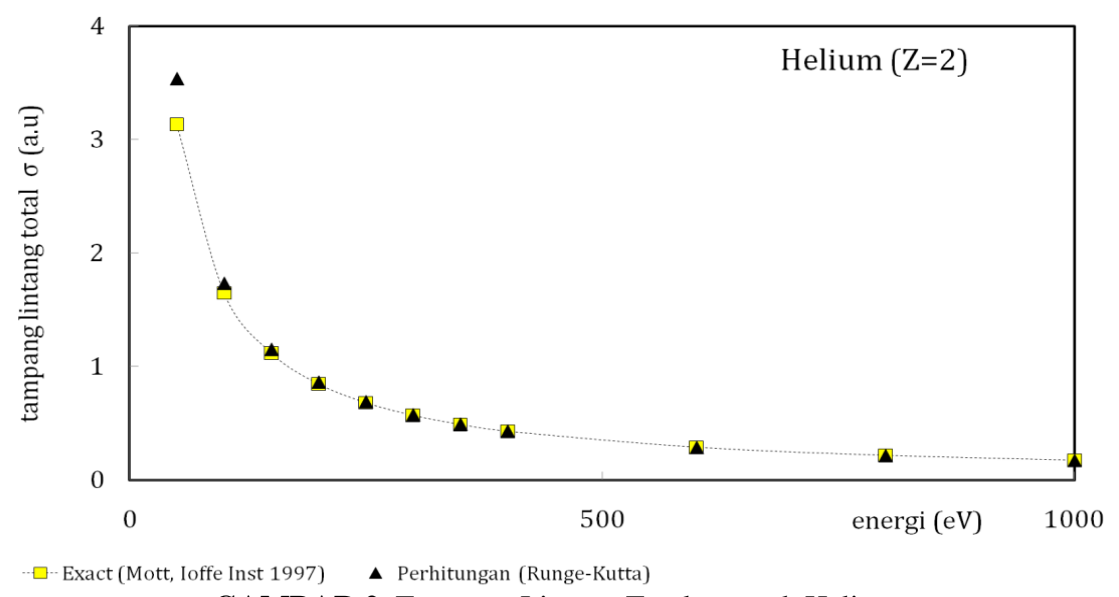

GAMBAR 2. Tampang Lintang Total $\sigma$ untuk Helium

\section{Hamburan $e$-Lithium}

Pada gambar 3 dapat dilihat tampang lintang total $\sigma$ Lithium, Z=3

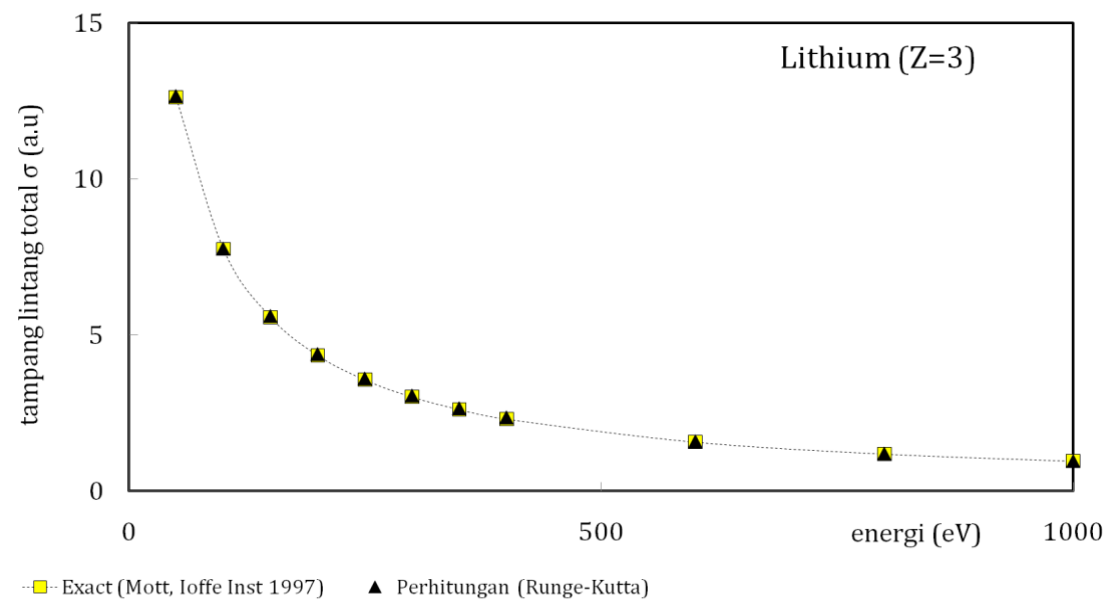

GAMBAR 3. Tampang Lintang Total $\sigma$ untuk Lithium

\section{Hamburan $\boldsymbol{e}$-Berilium}

Pada gambar 4 dapat dilihat tampang lintang total $\sigma$ Berilium, Z=4

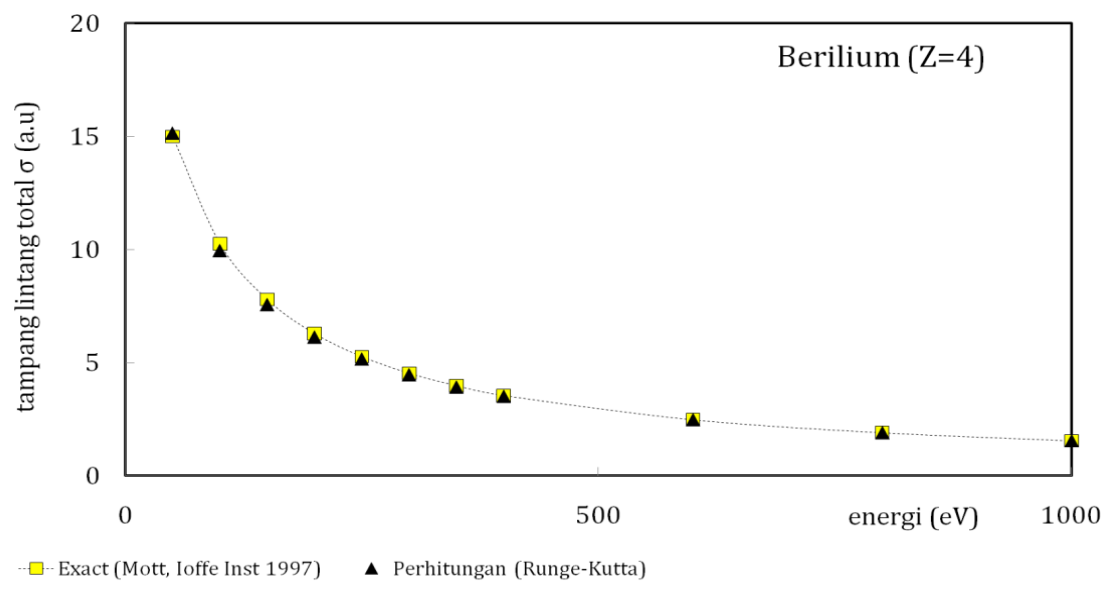

Gambar 4. Tampang Lintang Total $\sigma$ untuk Berilium. 


\section{Hamburan $\boldsymbol{e}$-Boron}

Pada gambar 5 Tampang lintang total $\sigma$ Boron, $\mathrm{Z}=5$

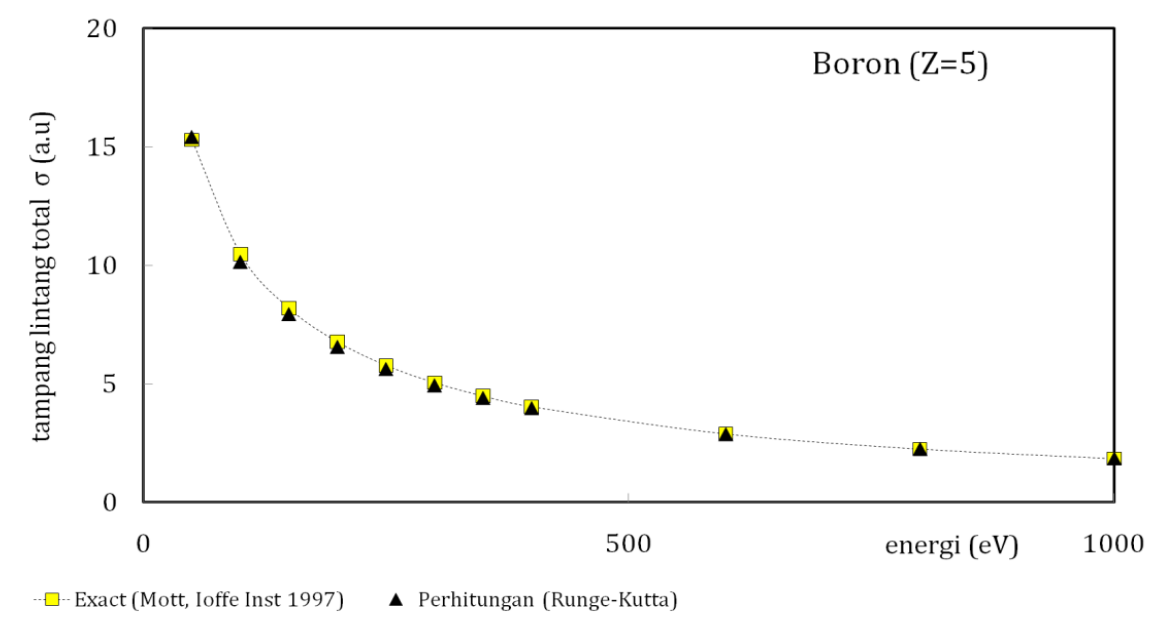

GAMBAR 5. Tampang Lintang Total $\sigma$ untuk Boron

\section{KESIMPULAN}

Dari penelitian ini dapat disimpulkan bahwa dengan menggunakan metode numerik RungeKutta untuk penyelesaian permasalahan hamburan partikel terlihat perbandingan hasil perhitungan dengan hasil eksak untuk model-model potensial sederhana dan pengamatan terhadap kelakuan konvergensinya menunjukkan bahwa perhitungan mampu memberikan hasil dengan ketelitian yang memadai meskipun perhitungan dilakukan dengan menggunakan komputer personal (PC) dengan kemampuan (resource) yang terbatas. Perhitungan ini (dengan menggunakan potensial Salvat) mampu menjelaskan secara kualitatif hamburan elektron-atom pada energi $200 \mathrm{eV}$ ke atas, terlihat dari konsistensi data pada energi tersebut atau lebih. Penggunaan metode numerik dapat memberikan solusi, bukan sekedar solusi alternatif, dalam penyelesaian permasalahan hamburan yang tidak dapat diselesaikan dengan metode analitik pendekatan Born yang telah diketahui umumnya. Kesalahan yang dihasilkan dalam contohcontoh perhitungan bernilai tidak lebih dari $0.1 \%$. Angka ini menunjukkan bahwa hasil perhitungan dapat dijadikan pembanding yang baik terhadap data eksperimen yang tersedia.

\section{DAFTAR PUSTAKA}

[1] Adhikari, S. K. (1998). Variational principles and the numerical solution of scattering. Canada: John Wiley \& Sons, Inc.

[2] Beiser, A., (1987). Concept of Modern Physics - Sixth Ed. New York:McGraw-Hill Companies, Inc.

[3] Ballentine E. Leslie, (1998). Quantum Mechanics A Modern Development, Singapore:World Scientific Publishing Co.Pte.Ltd.

[4] Davydov A.S (1965). Quantum Mechanics Vol.1. Frankfurt: Pergamon Press GmbH.

[5] Dimotakis P.E. (1980). Lectures on Quantum Physics and Applications. California:Author Self-Publication.

[6] Ernst Hairer, Syvert Paul Nørsett, and Gerhard Wanner (1993). Solving ordinary differential equations I: Nonstiff problems, 2nd ed. Berlin: Springer Verlag.

[7] Farina, J. E. G. (1973). Quantum Theory of Scattering Processes. Oxford: Pergamon Press Ltd.

[8] Geiger, H., Marsden, E,. (1909). On a diffuse Reflection of the $\alpha$-particles, Proc. R. Lond. A 1909 82, 495-500

[9] Holt, A.R. \& Santoso, B., (1974). On the Born series for scattering amplitudes. J. Phys. B, 7, 1018-1026. 
[10] John C. Butcher (2003). Numerical methods for ordinary differential equations. John Wiley \& Sons.

[11] Haeruman (2008). Perhitungan Energi Total Keadaan Dasar Atom Litium Dengan Metode Variasi: Skripsi, Sumedang: Unpad. 71

[12] Krane, K. S., (1992). Fisika Modern, Penerjemah Hans J. Wospakrik, Cetakan I, Jakarta: Penerbit Universitas Indonesia.

[13] Koonin, S.E. (1986). Computational physics. Redwood City, California: Addison-Wesley Publishing Company, Inc.

[14] Leonard, S. R., \& Thaler. (1967). Introduction to the Quantum Theory of Scattering. New York: Academic Press, Inc.

[15] Mott, N.F., \& Massey, H.S.F., (1965). The Theory of Atomic. 3rd ed. Oxford:Oxford University Press.

[16] Newton, R.G., (2002). Quantum physics : a text for graduate students. New York: Springer-Verlag New York, Inc.

[17] Salvat F., Martinez J. D., Mayor R., \& Parellada J., (1987). Analytical Dirac-HartreeFock-Slater screening function for atoms ( $Z=1-92)$. Phys. Rev. A, 36-2, 467-474

[18] Santoso, B. (1973). Investigation of Some Approximate Methods In Atomic Scattering Theory: PhD Thesis, Colchester, Essex: University of Essex.

[19] Schmid, E.W., Spitz, G., \& Lösch, W. (1990). Theoretical physics on the personal computer.2nd ed. Berlin: Springer-Verlag. 